\author{
(online) $=$ ISSN $2285-3642$ \\ ISSN-L = $2285-3642$ \\ Journal of Economic Development, Environment and People \\ Volume 4, Issue 1, 2015 \\ URL: $\underline{\text { http://jedep.spiruharet.ro }}$ \\ e-mail: office jedep@spiruharet.ro
}

\title{
The Women Employees within the Frame of Social Responsibility and an Analyse
}

\author{
Assistant Professor Hülya ÇAĞIRAN KENDIRLi ${ }^{1}$, \\ Lecturer Tuğba GÜLEN ${ }^{2}$ \\ Specialist Tuba KÜMBÜL ${ }^{3}$ \\ ${ }^{1}$ Hitit University, Çorum, Türkiye
}

\begin{abstract}
In many resources, corporate social responsibility is defined as an organization's ethic and responsible attitude towards all the partners in and outside of the instruction, it's taking the decisions accordingly and apply them.

In the researches that have been carried out recently, the concept of "partner" stands out. Institutions have relations with some certain partners such as consumers, advertisers and workers and so on as these groups include women as well. That is the reason why the studies should be carried out considering the women.

This concept has a great role in increasing the number of the social responsibility projects of the institutions that put emphasize on women.

Although Turkey signed CEDAW (Committee on the Elimination of Discrimination against Women) which is a legally binding contract and many contracts of ILO which aimed at protecting the equality of men and women, and made some certain laws to protect the equality, it was the 126th country of 130 countries according to the Index of Gender Mainstreaming report published by WEF (World Economic Forum) in 2013. In this regard, the need to replace women in the centre of social responsibility projects is inevitable.
\end{abstract}

Keywords: corporate social responsibility, gender equality, women

\section{JEL Codes: M14, M19}

\section{Introduction}

It has been widely observed that the concept of social responsibility has been the agenda both in daily conversations and academic work lately. Various establishments and organizations carry out a lot of a activities under the name of social responsibility projects or support many events which could be of help for society. In this scope, the works related to women have reached to quite a remarkable level.

Social responsibility is one of the main commitments which form the social structure of modern societies, local administration, organizations and establishments. The social responsibility concept is related

${ }^{2}$ Hitit University, Çorum, TürkiyeTel: +90 36421919 19, Fax: +90 3642191938

Email: hulyacagirankendirli@hitit.edu.tr, tugbagulen@hitit.edu.tr, tubakumbul@hitit.edu.tr 


\author{
(online) $=$ ISSN $2285-3642$ \\ ISSN-L = $2285-3642$ \\ Journal of Economic Development, Environment and People \\ Volume 4, Issue 1, 2015 \\ URL: $\underline{\text { http://jedep.spiruharet.ro }}$ \\ e-mail: office jedep@spiruharet.ro
}

to take the whole society into account in terms of the decisions taken for external environment. With its most common definition, social responsibility could be described as the a person's evaluation about positive and negative effects $\mathrm{s} / \mathrm{he}$ created on communal life and taking precaution against negative effects. (Kaya, 2008:15).

Nowadays the success of an establishment has increasingly been related to determining appropriate policies compatible with the society's values and continuing its activities without maximising its profit. Since the establishments are part of the system in their environment, their survival is bound to their adaptation to the changes in the system. (www.kurumsalsosyal.com). On the other hand, the establishments are the entities created by the society and general economic order. An establishment could live and become helpful and fruitful only if the society and economic order believe its necessity. It is valid for every establishment and organization whether it be big or small. Therefore, business administration has to observe the effects of the establishment on economic and social environment and their reactions (Akal, $2000,41)$.

\title{
2. Social Responsibility Concept and Corporate Social Responsibility
}

Corporate social responsibility appeared in H. Bowen's "Social Responsibilities of the Businessman" book which was published in 1953 for the first time as a concept. Bowen suggested that businessmen should be interested in social responsibility projects compatible with the society's values and aims.

According to the definition made by European Commission, corporate social responsibility is a concept which the establishments can integrate the social and environmental issues on voluntary basis with their interactions via organizational activities and social shareholders. Having social responsibility is not to meet official expectations rather invest in the relations of human capital, environment and shareholders by going beyond volunteerism (Commision of the European Communities, 2001:6).

United Nations Conference on Trade and Development (UNCTAD) approaches the corporate social responsibility from to what extent the establishments are concerned with the society's needs and aims perspective. According to UNCTAD, all the social groups expect certain roles and functions to be fulfilled in order to change the time through their own social change and evolution.

The expectations related to the establishments and especially the multinational ones undergo a tremendous change in an unexpected manner with the increase of their roles in the globalized society. Thus, discussions related to the social responsibility standards of multinational establishments and their applications is an integral part of developing a globalized society (UNCTAD, 1999:1).

Knowsn as ISO, strategic consultant group of International Standardization Organization on coporate social responsibility discusses corporate social responsibility as an approach which the organizations point at economic, social and environmental problems in way to promote the benefit for the people and society (AktanandBörü , 2007:11-13) 


\author{
(online) = ISSN $2285-3642$ \\ ISSN-L = 2285-3642 \\ Journal of Economic Development, Environment and People \\ Volume 4, Issue 1, 2015 \\ URL: $\underline{\text { http://jedep.spiruharet.ro }}$ \\ e-mail: office jedep@spiruharet.ro
}

It is possible to mention four common elements which are found in the definitions concerning corporate social responsibility concept in different sources (SönmezandBircan, 2004: 476-490):

1. Establishments have responsibilities beyond producing goods and service in order to make profit.

2. Among these responsibilities, contributing to the solution of social problems caused by the establishments themselves is present.

3. Establishments are not only in charge with their shareolders but also the environment which is their social shareholder.

4. Establishments do not only focus on economic values, they serve for humanistic values in a broad sense.

The point to take into consideration in these explanations is that corporate social responsibility could be realized not only in financial terms but in a non-financial manner, such as goods and service. Moreover, since it reflects the responsibility towards everyone who is directly or indirectly in interaction with, the establishments should take the society's needs and expectations from the development of the selection of social responsibility initiatives to the application of them into account. On the other hand, the social needs and expectations have constantly changed as a result of the conditions experienced throughout history. (Sert, 2012:34)

When the emergence and progress of social responsibility concept are investigated, the development of social responsibility concept starts with the appearance of civilizations and religions. The prime power which determined the behaviours of the people who made a living from trade was moral approaches. Social rules and laws were accepted as the secondary power. Humanity headed for endeavouring and dynamism from austerity and obedience with the effect of Renaissance and Reform and this transformation paved the way for discoveries and inventions. The common commercial custom during mercantilist period was shaped by measuring a country's wealth with its precious metals. In this period, helping the poor, finding a job for the unemployed was defined as the responsibilities of a state. As the Oriental society is viewed in the same period, it is possible to observe that the ideas were shaped by the effect of religious beliefs similar to Occidental society. However, it could be said that the social responsibilities progressed to a considerable extent in the East as a result of the Islamic regulations of certain topics, such as cooperation and social solidarity compared to the West. Serial production, which surfaced with Industrial Revolution occurring as a result of the use of steam power as an energy resource by James, made new management methods possible and the production gravitated from agriculture to industry. The technological developments in this era made the production of machines, which could produce at a sophisticated level, possible and mechanization created the need for manufacturization. Along with the increase of the big factories' numbers in 1800 s social responsibilities started to be defined in conceptual terms. Unionization movements increased and a transformation from the view which put the emphasis on the problems of workers rather than management solely based on industrialization was experienced. Social philosophy 


\author{
(online) = ISSN $2285-3642$ \\ ISSN-L = 2285-3642 \\ Journal of Economic Development, Environment and People \\ Volume 4, Issue 1, 2015 \\ URL: $\underline{\text { http://jedep.spiruharet.ro }}$ \\ e-mail: office jedep@spiruharet.ro
}

replaced individualistic philosophy. Industrial Revolution caused significant changes in the social habits and the responsibility concept became a focal point (Korkmaz, 2009:28-29).

People not only met their needs along with the increase in the production thanks to the industrialization but also they met other people's needs by starting in trade life. These developments started to form the social conscience and responsibility concepts in the USA and Europe. The concept of social responsibility became apparent with the emergence of industrialization and big establishments. Being one of the most significant economic depressions in the history and breaking out in 1929, the Great Depression led to unemployement and loss of production in many countries primarily the USA and the ones in Western Europe. It is seen in this period that the developments in social responsibility concept accelerated. The first meetings in which top-ranking managers attended were organized in order to discuss the social responsibilities and behaviour types by Sears Company in 1936. Non-governmental organizations which became important in 1960s and social movements like women rights and environmentalism shed light upon the development of social responsibilities (Göztaşve Baytekin, 2009:1999).

The establishments which collect energy, material and information and serve them as goods and service output and other establishments are obliged to get into contact with certain organizations and consumers. The elements such as cohabiting with the environment, the changes in social expectations, the relationship between corporate social responsibility and dignity of an establishment have a driving force in terms of the establishments' acting in accordance with social responsibility understanding.

In this context, the establishments are no long regarded as the organizations which solely produce goods and services, but organisms which take the worker's well-being into consideration, protect the environment and aim to provide the best service for the consumer. So to speak, everybody see eye to eye about the fact that the establishments are not only technical and economic organizations; on the contrary they are of a social dimension (Peltekoğlu, 2012: 190).

When the social responsibility defined, it is generally understood as an establishment which take precautions for protecting the nature and environment towards a sustainable growth. In fact, it is quite a deficient definition. An establishment is responsible for all the shareholders who could severely be affected by the decisions and activities it is involved in a direct or indirect relationship as well as the environment and society. It should be dwelled upon "stakeholder theory" in order to correctly understand the concept of corporatesocial responsibility. The establishments are in a relationship with different sectors, which form the society, in these days and their success depends on how successfully these relationships are managed. This concept is called "stake'olders" which describes this issue in the literature. It is possible to group the stakeholders into two: "in-house stakeholders" and "non-house stakeholders". In-house stakeholders consist of founder principal owners, shareholders, managers and employees. On the other hand, non-house stakeholders comprise of the sections, such as society, government, customers, suppliers, rivals and so forth. 


\author{
(online) $=$ ISSN $2285-3642$ \\ ISSN-L = 2285-3642 \\ Journal of Economic Development, Environment and People \\ Volume 4, Issue 1, 2015 \\ URL: $\underline{\text { http://jedep.spiruharet.ro }}$ \\ e-mail: office jedep@spiruharet.ro
}

\title{
3. Corporate Social Responsibility in Turkey and Woman
}

The society, among the stakeholders whom the establishments should treat socially and ethically, and the woman phenomenon in the society are undeniable realities which cannot be ignored. This phenomenon has a huge impact on the increase in the number of projects which put the women in the centre (Aktan-Börü,2007, p.13-14).

However, despite Turkey has taken several steps for protecting the equality of woman and man through laws, such as signing CEDAW (Convention on the Elimination of All Forms of Discrimination against Women), which has a legal binding, in 1985, various conventions of ILO for ensuring the equality of woman and man, and the Istanbul Convention (Convention on preventing and combating violence against women and domestic violence) in 2010, it was ranked as 120 out of 136 countries according to 2013 Social Institution Gender Inequality Index in a report prepared by World Economic Forum (WEF).

Women constitute $81 \%$ of the illiterate in Turkey. The representation rates of women in decisionmaking mechanisms are very low both in public and private sector. The rate of women in Grand National Assembly is only 14 (according to the results of general elections in 2011). Violence towards women still remains as a problem on the agenda. In-home care services are carried out by women to a great extent. In this context, the fact that women are in the centre of corporate social responsibility projects in Turkey appears both as a necessary and an unavoidable issue (Şenerve Demirdirek, 2014,p.3).

The "Corporate Social Responsibility Leaders" research, carried out by Capital magazine for $8^{\text {th }}$ times and being one of the leading studies which we could clearly see the data about the concept of social responsibility in Turkey has an important place. The research displays both the publics and business world's points of view about the CSR (Corporate Social Responsibility) studies performed by companies. As a result of plebiscite, Sabancı Holding is on the peak of responsibility league this year. Turkcell, Koç Holding, Yıldız Holding and Arçelik follow it respectively. It is highly striking to see that the top five has not changed for the last three years besides it shows that these companies have an established perception with regards to social responsibility field in the public eye.

GfKTürkiye General Director FulyaDurmuş states that "The research results show that almost half of the people still cannot make a definition of corporate social responsibility. The aids provided by CSR corporations are perceived as their activities in social and cultural fields. Every two people out of three think that companies have social responsibilities in this respect, but the rate of the people who finds these activities sufficient is quite low. While education and health are on the top of the fields which are expected to be invested, she also emphasized that there has been increase in the expectations of the public about the projects such as domestic violonce, women-children rights. (http://www.pazarlamasyon. com/ 2013/04/capital-dergisi-kurumsal-sosyal-sorumluluk-arastirmasini-yayimladi/) 


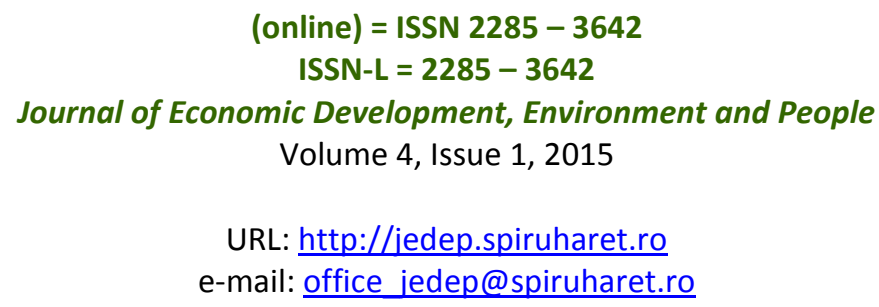

Table 1: The first 20 companies in the Corporate Social Responsibility Index in Turkey

\begin{tabular}{|c|c|l|l|}
\hline \multicolumn{5}{|c|}{ The first 20 companies in CSR according to the } \\
Business World \\
\hline \multicolumn{3}{|c|}{ CSR Leaders according to the Business World } \\
\hline 2013 & $\mathbf{2 0 1 2}$ & Company & Point \\
\hline $\mathbf{1}$ & $\mathbf{1}$ & Turkcell & 19,05 \\
\hline $\mathbf{2}$ & $\mathbf{2}$ & Koç Holding & 9,58 \\
\hline $\mathbf{3}$ & $\mathbf{3}$ & EczacıbaşıTopluluğu & 6,9 \\
\hline $\mathbf{4}$ & $\mathbf{4}$ & Sabancı Holding & 6,49 \\
\hline $\mathbf{5}$ & $\mathbf{7}$ & Borusan Holding & 4,17 \\
\hline $\mathbf{6}$ & $\mathbf{8}$ & Coca-Cola & 4,05 \\
\hline $\mathbf{7}$ & $\mathbf{5}$ & GarantiBankası & 3,51 \\
\hline $\mathbf{8}$ & $\mathbf{6}$ & İ̧Bankası & 2,74 \\
\hline $\mathbf{9}$ & $\mathbf{9}$ & Vodafone & 2,32 \\
\hline $\mathbf{1 0}$ & $\mathbf{1 0}$ & Yıldız Holding & 1,73 \\
\hline $\mathbf{1 1}$ & $\mathbf{1 2}$ & Akbank & 1,37 \\
\hline $\mathbf{1 2}$ & $\mathbf{1 1}$ & Türk Telekom & 1,19 \\
\hline $\mathbf{1 3}$ & $\mathbf{1 4}$ & Unilever & 1,01 \\
\hline $\mathbf{1 4}$ & $*$ & Doğuş Holding & 0,89 \\
\hline $\mathbf{1 5}$ & & Eti & 0,83 \\
\hline $\mathbf{1 6}$ & $\mathbf{1 3}$ & Procter\&Gamble & 0,77 \\
\hline $\mathbf{1 7}$ & $\mathbf{1 5}$ & Arçelik & 0,65 \\
\hline $\mathbf{1 8}$ & $\mathbf{1 9}$ & AnadoluSigorta & 0,6 \\
\hline $\mathbf{1 9}$ & $* / 18$ & $\begin{array}{l}\text { Doğan } \\
\text { Holding/DoğuşOtomotiv }\end{array}$ \\
\hline $\mathbf{2 0}$ & $\mathbf{1 8 / 1 6}$ & EfesPilsen/Opet & 0,54 \\
\hline Not on last year's list & \\
\hline
\end{tabular}




\author{
(online) = ISSN $2285-3642$ \\ ISSN-L = $2285-3642$ \\ Journal of Economic Development, Environment and People \\ Volume 4, Issue 1, 2015 \\ URL: http://jedep.spiruharet.ro \\ e-mail: office jedep@spiruharet.ro
}

As shown by the research results, the companies which work on issues like "domestic violonce" and "women-children rights" within the context of Corporate Social Responsibility become prominent both in business world and public opinion.

When the projects of Turkcell, which came first in this research, on women and children are investigated, there are rip-roaring projects such as "Kardelen", providing scholarship for 95,000 girls, Women Power for Economy, and Zero Tolerance for Violonce towards Women. Following this, there are striking projects of Koç Holding as follows: For my country and Vocational School: A matter of country as well as Let the hearts be together, Smiling eyes, We will grow thanks to Science, P\&G Prima Conscience Mother Healthy Baby by Eczacıbaşı Holding and Pink Ribbon against Breast Cancer by Avon.

When we look at other inspiring social responsibility project examples in Turkey, we see the subjects related to family and child are treated more closely than other topics. These campaigns are as follows: Stop Domestic Violonce by Doğan Holding, Daddy, Send me School; Harmony in Education by Arçelik; Attentive Child, Warns you against Home Accidents by Aygaz; Brisa- My headlights are on, so is my way by Sabancı Holding; Doğuş Automotive- Traffic is Life by Doğuş Holding; HSBC Lovers Project by HSBC, and Clean Toilet by OPET.

\title{
4. Results and Discussion
}

Besides the concept of Social Responsibility in Turkey, the concept of increasing the woman's political, economic and social value in the society appears as an important issue which should be embraced by the society in the first place. Determining the women as a focal point in the social responsibility projects carried out by the corporations in Turkey will lend impetus to this movement.

Today, that the corporations focusing solely on profit tarnish the image of them to a great extent and it is a fact reflecting on the studies. The data reveal that the establishments develop, globalize and sustain their development as long as the society in which they live prospers. Moreover, it has been observed in the studies carried out in Turkey that the social responsibility projects which centre upon the protection and development of women attract more attention and become more successful compared to the others.

\section{References}

[1] Peltekoğlu, F.B. (2012), Halklailiş̧kiler Nedir?, Beta Basımevi , 7. Baskı, İstanbul

[2] Aktan, C.C.and Börü, D. (2007) Kurumsal Sosyalsorumluluk İşletmelerve Sosyal Sorumluluklar, Editör :Çoşkun Can Aktan, Kurumsal Sosyal Sorumluluk, İGiAD Yayınları ,istanbul

[3] Sönmez, F. and Bircan, K. (2004). Işsletmelerin Sosyal Sorumluluğuve Çevre Sorunlarında Ekonomik Yaklaşımlar. Yaklaşım Dergisi. Yıl:12, Sayı:133, s.476-490

[4] Çorumiş Gücü Piyasası Analiz Raporu, (2013), Çorum Çalışmave İşKurum il Müdürlüğü, Çorum

[5] Petenkaya, Z.I. (2010) Devletin Değişimive Özel Sektör: Dünyadave Türkiye'de Sosyal Sorumluluk Anlayışı, Anakara Üniversitesi Sosyal Bilimler Enstitüsü, Yüksek Lisans Tezi

[6] Commision of the European Communities, (2001), ec.europa.eu/.../lb_com_2001_0370_en.pdf 


\author{
(online) = ISSN $2285-3642$ \\ ISSN-L = 2285 - 3642 \\ Journal of Economic Development, Environment and People \\ Volume 4, Issue 1, 2015 \\ URL: http://jedep.spiruharet.ro \\ e-mail: office jedep@spiruharet.ro
}

[7] Türkiye'de Özel Sektörün Kurumsal Sosyal Sorumluk Anlayışına İlişkin Yarar Algısı: Kurumsal Sosyal Sorumluluk Faaliyetlerinin Duyurulmasında Web Sitelerinin Kullanılması, Dr. Nuray Yılmaz Sert http://www.ajit-e.org/?menu=pages \&p=details of article\&id=56 35

[8] Sosyal Sorumluluk Kampanyaları İle Çocukların Bilinçlendirilmesive Eğitimi Türkiye'den Bir Uygulama Örneği: Aygaz Dikkatli çocuk kazalarakarşı bilinçlendirme kampanyası

[9] GÖZTAŞ, A. and BAYTEKiN, P., (2009), Sosyal Sorumluluk Kampanyalari ille Çocuklarin Bilinçlendirilmesi Ve Eğitimi Türkiye'den Bir Uygulama Örneği: Aygaz 'Dikkatli Çocuk' KazalaraKarşi Bilinçlendirme Kampanyasi”, Journal of YaşarUniversty, No.13. Vol 4, ss.1997-2015.

[10] Şener, Ü. And Demirdirek, H. (2014), Toplumsal Cinsiyete Duyarlı Veri Çalışması,01.01.2014 http://www.tepav.org.tr/upload/files/haber/1399033411-7.TCDV Toplumsal Cinsiyete Duyarli Veri Calismasi_Egitimi.pdf Erişim tarihi13.07.2014

[11] AKAL, Z.,(2000) İşletmelerde Performans Ölçümve Denetimi, Milli Prodüktivite Merkezi, Yayın No:173, Anakara.

[12] KAYA, S. (2008) İşletmelerde Sosyal Sorumlulukve SA 8000 (Social Accountability) Standardı, AR- GE, http://www.izto.org.tr, Erişim Tarihi: 29.09.2014 